\title{
Hogyan hat a mobileszköz-használat az óvodások figyelmére és társas-kognitív készségeire?
}

\author{
Konok Veronika ${ }^{1}$, Peres Krisztina ${ }^{1,2,3}$, Ferdinandy Bence ${ }^{4}$, \\ Jurányi Zsolt ${ }^{1}$, Bunford Nóra ${ }^{5}$, Ujfalussy Dorottya Júlia ${ }^{1}$, \\ Réti Zsófia ${ }^{1}$, Kampis György ${ }^{1}$ és Miklósi Ádám ${ }^{1}$
}

\author{
${ }^{1}$ Eötvös Loránd Tudományegyetem TTK Etológia Tanszék \\ ${ }^{2}$ Eötvös Loránd Tudományegyetem Pszichológiai Doktori Iskola \\ ${ }^{3}$ Eötvös Loránd Tudományegyetem Pszichológiai Intézet \\ ${ }^{4}$ MTA-ELTE Összehasonlitó Etológiai Kutatócsoport \\ ${ }^{5}$ Természettudományi Kutatóközpont KPI, \\ Lendület Fejlödéstani és Transzlációs Idegtudomány Kutatócsoport
}

\begin{abstract}
Absztrakt
Az érintőképernyős mobileszközöket (ÉKM: okostelefonok és tabletek) egyre többet és egyre fiatalabb korban használják a gyerekek. Ekkor az agy még nagyon plasztikus, így az ÉKM-használat befolyásolhatja a kognitív fejlődést, ami új kihívásokat támaszt a szülőkkel és pedagógusokkal szemben. Egy keresztmetszeti vizsgálatban összehasonlítottuk az ÉKM-eszközöket gyakran használó és az ilyen eszközöket nem használó óvodás korú gyerekek (szelektív és megosztott) figyelmi és szociokognitív képességeit. Majd kísérletesen vizsgáltuk, hogy miképp befolyásolja a gyerekek figyelmi teljesítményét, ha előzőleg (előkezelés) egy gyors vagy lassú sebességű digitális játékkal vagy egy nem digitális játékkal játszanak. A szelektív figyelmi feladatban a gyerekek figyelmére (ÉKM-használattól függetlenül) a globális fókusz volt jellemző (jobban teljesítettek, ha az egészre kellett figyelni, mint ha a részletre), a megosztott figyelmi feladatban azonban az ÉKM-használók atipikus, lokális fókuszt mutattak (jobban teljesítettek, amikor a kis ábra volt a célinger, mint amikor a nagy), és teljesítményük a globális próbákban elmaradt az ÉKM-eket nem használó gyerekekétől. Az ÉKM-használók gyengébb tudatelméleti teljesítményt mutattak, viszont az érzelmek felismerésében nem különböztek az ÉKM-et nem használóktól. Az előkezelésen alapuló vizsgálatunk a figyelmi működéssel kapcsolatos eredményeket kísérletesen is megerősítette: a tesztet megelőzően digitális játékkal játszó gyerekek globális fókuszt mutattak a szelektív feladatban és lokális fókuszt a megosztott figyelmi feladatban, a nem-digitális játék után viszont mindkét feladatban globális fókusz volt jellemző. Míg a nem-digitális és a lassú digitális játékkal játszó gyerekek a szelektív figyelmi feladatban jobban teljesítettek, mint a megosztottban, addig a gyors digitális játékkal játszók nem mutattak ilyen előnyt a szelektív figyelmi feladatban. Eredményeink azt mutatják, hogy az ÉKM-eszközök rövid- és hosszútávú hasz-
\end{abstract}


nálata és azon belül a digitális játékokkal való játék lokális figyelmi fókuszhoz vezet, talán azért, mert a digitális képernyők lokális információkban gazdagok, és ritkán látszódik egyben az egész kép. A gyors digitális játék, azáltal, hogy párhuzamosan több ingerre kell figyelni, a megosztott figyelmet fejleszti, de a szelektív figyelmet nem. Az ÉKM-használat elveszi az időt a társas tevékenységektől, ami magyarázhatja, hogy az ÉKM-használóknak nehézségeik vannak a komplexebb szociokognitív képességek terén (tudatelmélet). Eredményeink fontos ismereteket nyújtanak és irányt mutatnak a pedagógia és a pszichológia számára.

Kulcsszavak: érintőképernyős mobileszközök, digitális játék, figyelem, szociokognitív képességek

\section{Bevezetés}

Az utóbbi évtizedben a technológiai fejlődés és konkrétabban az érintőképernyős mobileszközök (ÉKM-ek) megjelenésével jelentősen megváltoztak a kisgyermekeket érő tipikus élmények. Egy hazai kutatásban kimutattuk (Konok, Bunford, \& Miklósi, 2020), hogy egyre korábbra tolódik az ÉKMeszközök használatának kezdete: míg 2012-ben a három évnél fiatalabb gyerekeknek mindössze néhány százaléka használt okostelefont vagy tabletet, addig 2016-ban ez az arány már 40\% körül volt. (1. ábra) Az óvodáskorú gyerekeknél pedig még magasabb az ÉKM-használók aránya: Magyarországon 2016-ban a 3-4 évesek 54\%-a, a 4-5 éveseknek pedig már 61\%-a használt ilyen eszközöket (2.ábra), átlagosan napi fél órát ${ }^{1}$.

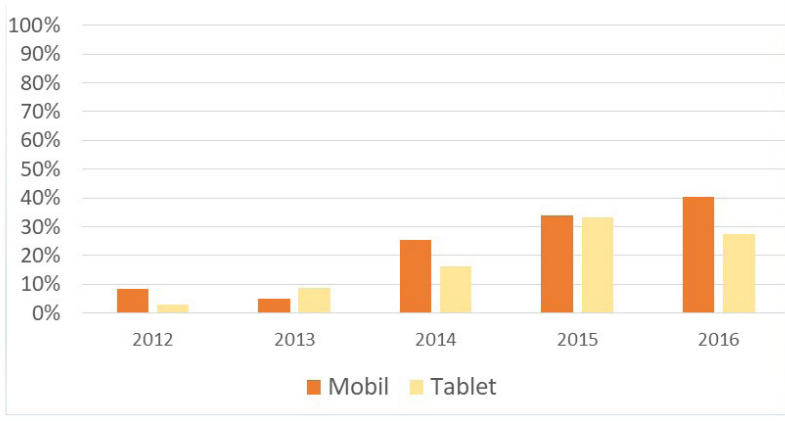

1. ábra

A 3 éves kor alatti mobil-és tablethasználat növekedése Magyarországon.

${ }^{1}$ A felmérés nem reprezentatív, 1270 szülő bevonásával készült. 


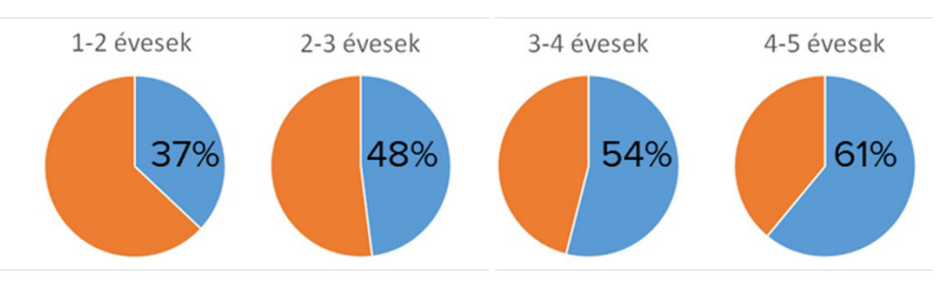

2. ábra

Az érintőképernyős mobileszközöket használó és nem használó gyerekek aránya különbözö korosztályokban 2016-ban.

A népszerűség és intenzív használat ellenére nagyon keveset tudunk arról, hogy milyen hatással van az ÉKM-eszközök használata a gyerekek kognitív, érzelmi, társas vagy motoros fejlődésére. A régebbi típusú médiával (például televízió) kapcsolatban már sokkal több kutatási adat áll rendelkezésünkre, és ezek többsége szerint a korai televíziónézés káros hatással van a későbbi figyelmi, kognitív, végrehajtó és nyelvi fejlődésre (Christakis, 2009). Azonban az ÉKM-eszközök több technikai szempontból is eltérnek a televíziótól (például interaktív használati mód, speciális szenzomotoros ingerlést nyújtó érintőképernyő, többféle tevékenységre való alkalmasság), és a gyerekek gyakrabban használják ezeket magányosan, szemben a televízióval, amelyet jellemzően a szülőkkel együtt néznek (Connell, Lauricella, \& Wartella, 2015).

Az egyik leggyakrabban végzett tevékenység az ÉKM-eszközökön a digitális játék (Konok et al., 2020), amely szintén eltérővé teszi az ÉKM-használatot a TV-nézéstől, azonban hasonlóvá a más eszközökön (PC, konzoljátékok) játszott videójátékokhoz. Utóbbiak esetében a kutatások általában azt találták, hogy serdülő- és felnőttkorban a videójátékok a figyelmi folyamatok számos aspektusát fejlesztik (Green \& Bavelier, 2008). Azonban a számítógépes és konzoljátékokhoz képest a gyerekek fiatalabb korban kezdenek játszani az ÉKM-eszközökön (Kabali et al., 2015), amikor még sokkal plasztikusabb az agy, és több normatív ingerre van szükség a megfelelő fejlődéshez (Hubel \& Wiesel, 1963; Schoenmaker et al., 2015). Ezért is lehet, hogy a TV-nézés, amelyet a gyerekek sokkal korábban kezdenek, káros hatással van a figyelemre, míg a számítógépes vagy konzolos videójátékok, amelyeket már nagyobb gyerekek, kamaszok és felnőttek játszanak, pozitív hatással.

\section{Milyen mechanizmusokon keresztül hathatnak az ÉKM-ek?}

Az egyik mechanizmus, amelyen keresztül az ÉKM-ek károsan hathatnak a kognitív funkciókra, köztük a figyelemre és a végrehajtó funkcióra, az a fejlődő agy túlingerlése (Christakis, 2009). Egerekkel végzett kísérletek alapján a túlingerlés (túlzott, a normatívtól eltérő ingerlés) fokozott aktivitást, kockázatvállalást, csökkent mértékű rövidtávú memóriát és kognitív funk- 
ciót eredményez (Christakis, Ramirez, \& Ramirez, 2012). A videók és videójátékok bővelkednek a gyors, intenzív, figyelemfelkeltő, kiugró (száliens), ugyanakkor a mélyebb megértést nem segítő ingerekben (például gyors tempó, gyakori vágások, villódzó fények, hanghatások; Gentile \& Khoo, 2012; Goodrich, Pempek, \& Calvert, 2009). A gyors és stimuláló ingerek pedig az exogén, ingervezérelt figyelmi folyamatoknak kedveznek, az endogén, célvezérelt figyelmi folyamatok kárára (Landhuis, Poulton, Welch, \& Hancox, 2007), emiatt negatívan befolyásolhatják a végrehajtó figyelem, azaz a figyelmi kontroll fejlődését. Azonban eddig még nem vizsgálták módszeres kísérleti manipulációval, hogy különböző mértékű ingerléssel járó - például különböző sebességü - ÉKM-tartalmak valóban máshogy hatnak-e a kognitív folyamatokra, köztük a végrehajtó funkcióra vagy a figyelemre.

Az ÉKM-eszközök egy másik megkülönböztető jegye, hogy a képernyőn megjelenő kép rendkívül részletgazdag, ugyanakkor szinte sosem látható egyszerre az egész (Gestalt), hiszen - akár egy játék, egy weboldal vagy a kezdőképernyő használatakor - görgetéssel (scrolling) vagy lapozással (sweeping) lehet csak belátni a teljes képet (Liu, 2005). Lehetséges, hogy ez a néző figyelmét sokkal inkább a részletek felé irányítja. Az ÉKM-használat precíz finommozgást igényel, ami szintén a részletek felé irányítja a figyelmet (Job, van Velzen, \& de Fockert, 2017). A gyerekek és a felnőttek is jellemzően globális módon dolgozzák fel a látott képet, azaz általában hamarabb veszik észre a nagyobb, globális mintázatot, mint az apró részleteket (Plaisted, Swettenham, \& Rees, 1999). Elképzelhető ugyanakkor, hogy az ÉKM-használat ezt a tendenciát befolyásolja, hasonlóan más tapasztalatokhoz vagy a kulturális környezethez (Miyamoto, Nisbett, \& Masuda, 2006).

Az ÉKM-eszközök nem csak speciális szenzoros és szenzomotoros ingerlést nyújtanak, amellyel befolyásolhatják a gyermekek kognitív készségeit, hanem azáltal is hatással lehetnek a gyerekekre, hogy használatuk elveszi az időt más, fejlődésileg fontos tevékenységektől (helyettesítési hatás). A társas - különösen a szülőkkel és testvérekkel folytatott - interakciók, illetve a szimbolikus és kreatív játékok nélkülözhetetlenek a társas-kognitív és társas-emocionális készségek vagy a végrehajtó funkció megfelelő fejlődéséhez (Ashiabi, 2007; Dunn, Brown, \& Beardsall, 1991; Fonagy, Steele, Steele, \& Holder, 1997). Márpedig kutatások kimutatták, hogy az elektronikusmédiahasználat (például TV-nézés) ezektől veszi el az időt (Vandewater, Bickham, \& Lee, 2006), és a szülő-gyerek interakciók minőségével is negatív összefüggésben áll, bár az okság kétirányú is lehet (Kirkorian, Pempek, Murphy, Schmidt, \& Anderson, 2009). Ezért nem meglepő, hogy a nagyobb mértékü TV-nézés gyengébb tudatelméleti készségekkel jár együtt (Nathanson, Sharp, Aladé, Rasmussen, \& Christy, 2013). Az ÉKM-eszközök társas-kognitív készségekre gyakorolt hatásáról eddig nem született tanulmány, azonban annyit tudunk, hogy egy képernyőmentes gyerektábor során fejlődtek a gyerekek ilyen jellegü készségei azokhoz a gyerekekhez képest, akik továbbra is a normál hétköznapokat élték (Uhls et al., 2014). 
Az elmondottak miatt arra voltunk kíváncsiak, hogy óvodás gyerekek esetében az ÉKM-et sokat használó és az ilyen eszközöket egyáltalán nem használó gyerekek különböznek-e a társas-kognitív, társas-érzelmi és a figyelmi kontroll készségekben. Ezt az összehasonlító, korrelatív jellegű vizsgálatot kiegészítettük egy kísérletes vizsgálattal is, hogy oksági folyamatokra is következtethessünk. Mivel az ÉKM-használat hosszútávú manipulálása etikai aggályokat vet fel, ezért egy egészen rövid ÉKM-használatnak tettük ki a gyerekeket, és így vizsgáltuk az azonnali, rövid távú hatást a figyelmi folyamatokra. A kísérleti csoportba sorolt gyerekek a tesztet megelőzően az ÉKM-en egy digitális játékot használhattak, amelynél a játék gyorsaságát változtattuk (túlingerlés).

\section{Az ÉKM-használat összefüggése a gyerekek figyelmi és társas- kognitív készségeivel (összehasonlító vizsgálat)}

\section{Módszer}

A résztvevők toborzása a korábbi (Konok et. al., 2020) kérdőíves kutatásban résztvevők közül történt. Az adatfelvétel az ELTE TTK Etológia Tanszék tesztszobájában zajlott a szülők jelenlétében. A vizsgálatban olyan óvodás gyerekek (N=40; 18 fiú és 22 lány; kor: 4,29-6,22 év, medián: 4,96 év) teljesítményét hasonlítottuk össze tudatelméleti, érzelemfelismerési és figyelmi tesztekben, akik viszonylag sokat használnak ÉKM-et (minimum napi 15 percet és legalább egy éve használják aktív formában is, azaz játszanak rajta, vagy ők indítanak el videókat, alkalmazásokat), vagy egész életükben legfeljebb néhány alkalommal használtak ÉKM-eszközt. A 20 ÉKM-et használó és a 20 ÉKM-et nem használó gyerekek csoportja nem különbözött egymástól demográfiai változókban (kor, nem, szülői iskolázottság). Az ÉKMhasználó gyerekek átlagos napi eszközhasználata 93,5 perc volt $(\mathrm{SD}=91,52$ perc), átlagosan 3 éve használták az eszközt a vizsgálat idején, leggyakrabban játékra és videónézésre.

A figyelem mérésére a Navon-teszt (Navon, 1977) egy óvodáskorúakra adaptált változatát (Sjöwall, Backman, \& Thorell, 2015) módosítottuk (a programot Ferdinandy Bence fejlesztette). A feladat során, a számítógép képernyőjén nagy ábrák (nap, csillag, hóember) jelennek meg, melyek ezekkel kongruens vagy inkongruens kisebb ábrákból (nap, csillag vagy hóember) állnak. (3. ábra) A gyerekeknek két gomb („maci-ébresztő gomb” és „macialtató gomb") valamelyikének megnyomásával kellett válaszolniuk attól függően, hogy a célinger (nap) jelen volt-e. (A keretmese szerint a téli álmot alvó macit akkor és csak akkor kell felébreszteni, ha süt a nap.) A teszt két szelektív és egy megosztott figyelmi altesztből állt. A szelektív figyelmi altesztekben vagy csak a nagy ábrára (szelektív-globális alteszt), vagy csak a kis ábrára (szelektív-lokális alteszt) kellett figyelni, és akkor jelezni, ha azon a szinten az ábra a nap volt. A megosztott figyelmi altesztben a nagy és a kicsi ábrára 
is kellett figyelni, és ha bármelyik a célinger volt, akkor jelezni. Mindegyik alteszt 9 próbából állt. Mértük a hibázást és a reakcióidőt (ms).
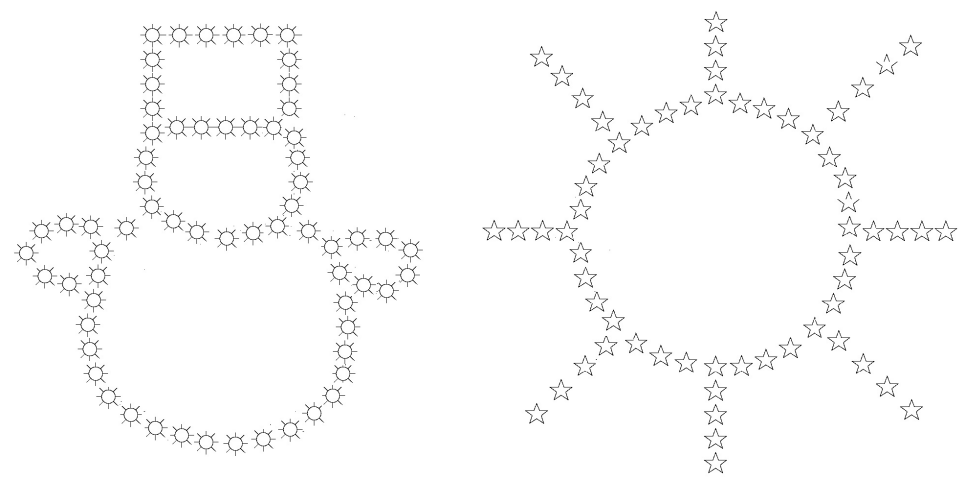

3. ábra

Példák a Navon-teszthez használt összetett ingerekre.

A tudatelméleti teljesítményt a váratlan tartalom ('Smarties') teszttel (Gopnik \& Astington, 1988; Hogrefe, Wimmer, \& Perner, 1986) és a valóslátszólagos érzelem teszttel mértük. (egy történet a Harris, Donnelly, Guz, \& Pitt-Watson, 1986 féle verzióból; Wellman \& Liu, 2004 által módosítva). A váratlantartalom-tesztben a gyerekeknek egyrészt egy idegen személynek kell hamis vélekedést tulajdonítani, másrészt a korábbi téves vélekedésüket kell felidézniük ( 0,1 vagy 2 pont adható rá). A valós-látszólagos érzelem tesztben azt vizsgáljuk, hogy a gyerekek felismerik-e, hogy a megélt és a kifejezett érzelem eltérhet egymástól ( 0 vagy 1 pont). A két teszt pontszámából egy tudatelméleti összpontszámot képeztünk (0-tól 3-ig terjedő értékekkel).

$\mathrm{Az}$ érzelemfelismerés méréséhez $12 \mathrm{db}$, arckifejezést megjelenítő fényképen (Radboud Face Database; Langner et al., 2010) és $6 \mathrm{db}$, testbeszédet megjelenítő videófelvételen (EU-Emotion Stimulus Set; O’Reilly et al., 2016) kellett felismerniük a gyerekeknek a megfelelő érzelmeket (öröm, szomorúság, félelem, düh, undor vagy meglepetés).

\section{Eredmények}

Figyelem

Először összehasonlítottuk, hogy az ÉKM-használók és nem használók különböző teljesítményt (válaszok helyessége, és a helyes válaszok reakcióideje) mutatnak-e az egyes altesztekben függetlenül attól, hogy a célinger a lokális vagy a globális szinten volt-e jelen. Az általános és általánosított lineáris 
kevert modellek (GLMM és GzLMM) kimutatták, hogy a két csoport között nem volt különbség, azonban a teszttípusnak volt hatása $\left(\mathrm{F}_{2 ; 835}=24,714\right.$; p<0,001): az ÉKM-használattól függetlenül a gyerekek gyorsabbak voltak és több helyes választ adtak a szelektív altesztekben, mint a megosztott altesztben, azon belül pedig a szelektív-globális altesztben teljesítettek legjobban.

Ha azonban csak a megosztott figyelmi feladatban nyújtott teljesítményt vizsgáltuk, akkor érdekes interakciós hatást kaptunk $\left(\mathrm{F}_{7 ; 266}=3,916 ; \mathrm{p}=0,002\right)$. Az inkongruens próbákban (amikor a kis és a nagy ábra különböző volt), az ÉKM-használó gyerekek lassabban reagáltak az EKM-et nem használó gyerekekhez képest, de csak a globális próbákban, vagyis amikor a nagy ábra volt a célinger. (4. ábra) Az ÉKM-használó gyerekek a lokális próbákban jobban teljesítettek, mint a globális próbákban, míg az ÉKM-et nem használók globális előnyt mutattak. Abban viszont nem volt különbség a két csoport között, hogy mennyi helyes választ adtak, elmondható, összességében igen alacsony volt a hibázások száma, és különbséget csak az okozott, hogy kongruens vagy inkongruens volt a próba; a kongruens próbákban mindenki jobban teljesített $\left(\mathrm{F}_{3 ; 318}=8,944 ; \mathrm{p}<0,001\right)$.

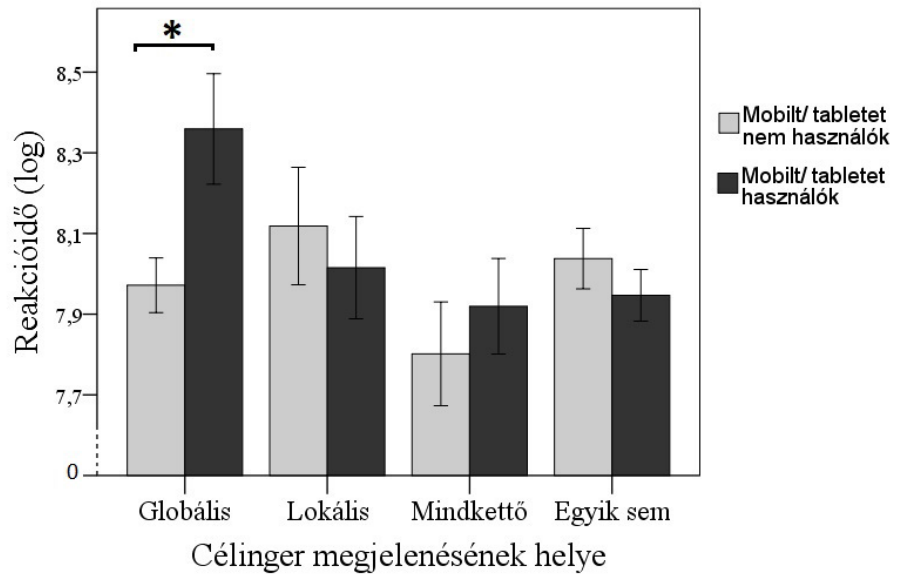

4. ábra

Reakcióidö (átlag + standard hiba) a Navon-teszt megosztott figyelmi altesztjében az ÉKM-et (mobilt/tabletet) használó és nem használó gyerekeknél a célinger különbözö megjelenési szintjei esetén (a célinger a hierarchikus ábra globális/lokális/ mindkét/ vagy egyik szintjén sem szerepelt).

A szelektív altesztekben viszont se a válaszhelyességre, se a reakcióidőre nem volt hatása az ÉKM-használatnak. Ezekben a feladatokban a gyerekek - függetlenül az ÉKM-használattól és attól, hogy épp a kis vagy a nagy ábra 
volt a célinger - gyorsabbak voltak a szelektív-globális feladatban, azaz amikor a nagy ábrára kellett figyelni, mint a szelektív-lokális feladatban, azaz amikor a kis ábrára kellett figyelni $\left(\mathrm{F}_{1 ; 562}=8,270 ; \mathrm{p}=0,004\right)$.

\section{Társas-kognitív készségek}

Az ÉKM-használó gyerekek rosszabbul teljesítettek a tudatelméleti tesztekben, mint az ÉKM-et nem használók (Wald $\chi 2=3,915 ; p=0,048$ ). Az érzelemfelismerésben azonban nem volt köztük különbség (Wald $\chi^{2}=0,175 ; \mathrm{p}=0,676$ ).

\section{Rövid idejü ÉKM-játékok és azok sebességének hatása óvodások figyelmi folyamataira - kísérletes vizsgálat}

Ebben a kutatásban azt vizsgáltuk, hogy egy rövid idejű digitális (ÉKM-es) játék milyen hatással van tipikus fejlődésű, óvodáskorú gyerekek figyelmi folyamataira, illetve a játékok sebessége (lassú vagy gyors játék) befolyásolja-e a figyelmi müködést. A vizsgálat során a gyerekeket három csoportba osztottuk, ahol a résztvevők a figyelmet mérő feladatok előtt (1) egy ÉKM-en futó, lassú, illetve (2) gyors digitális játékkal játszottak, vagy (3) a kontrollcsoport egy „hagyományos”, azaz nem-digitális játékkal játszott. Az előzőleg bemutatott összehasonlító vizsgálat eredménye alapján azt feltételeztük, hogy a digitális játék után elvégzett teszt során a gyerekek a részletekre figyelnek inkább - különösen a gyors digitális játékot követően -, míg a nem-digitális játékkal játszó gyerekek inkább globális fókuszt mutatnak. Korábbi megfigyelések alapján az vártuk, hogy az intenzívebb ingerlés (túlingerlés) következtében a gyors digitális játékkal játszó gyerekek figyelmi teljesítménye öszszességében rosszabb, mint a lassú digitális játékkal játszó gyerekeké.

\section{Módszer}

A résztvevők toborzása az Alfa Generáció Labor honlapján (www.alfageneracio. hu) és közösségi oldalán történt, illetve a labor korábbi, kérdőíves kutatásaiban résztvevőket is felkerestük e-mailben. Az adatfelvétel az ELTE TTK Etológia Tanszékén működő Alfa Generáció Labor tesztszobájában zajlott a szülők jelenlétében. A kutatásban összesen 56 fő vett részt (24 fiú és 32 lány; életkor: 3,87-6,63 év; medián = 4,92 év). Az úgynevezett lassú digitális csoportban 17 fö, a gyors digitális csoportban 19 fó, a nem-digitális csoportban 20 fö volt.

\section{Eszközök, eljárás}

A kísérleti kezelés háromszor két perces volt a következő elrendezésben: gyors digitális játék - gyors digitális csoport, lassú digitális játék - lassú digitális csoport, nem-digitális játék - nem-digitális kontrollcsoport. (5. ábra) A digitális játék egy, a kutatócsoportunk (Jurányi Zsolt) által fejlesztett, tableten játszható, lufipukkasztó játék volt, ahol a gyerekeknek minél több, fel- 
fele szálló lufit kellett kipukkasztani az ujjukkal. A játék sebessége állítható volt: a gyors digitális csoportban a lufik 3 másodperc (s) alatt tették meg az utat a képernyő aljától a tetejéig, és két lufi megjelenése között $650 \mathrm{~ms}$ telt el. A lassú digitális csoportban 5 másodperc (s) volt az emelkedési idő, két lufi megjelenése között pedig $850 \mathrm{~ms}$ telt el. A kontrollcsoportban egy olyan nem-digitális játékkal („whack-a-mole”) játszottak a gyerekek, ami jellegében hasonlított egy digitális játékhoz: itt az apró lyukakból rövid időre kiemelkedő vakondokat kellett gyorsan ujjal visszanyomni a helyükre.
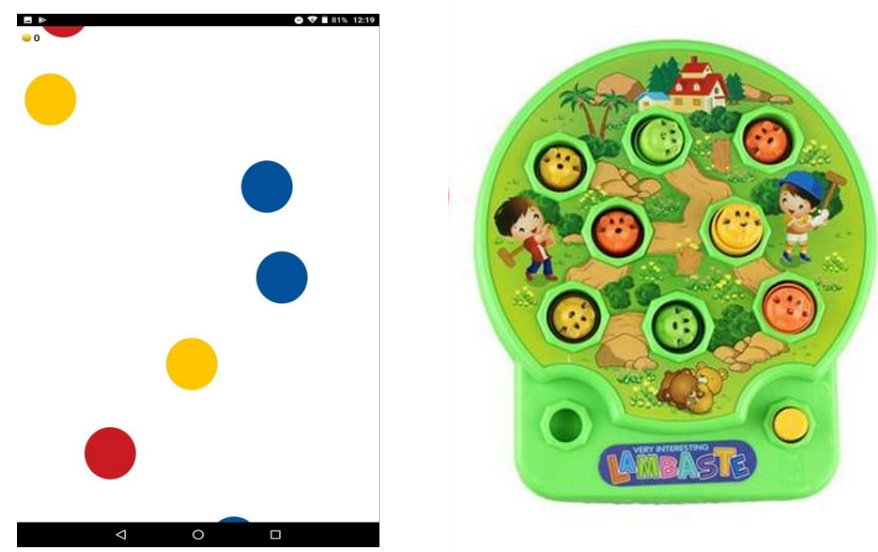

5. ábra

A kisérleti és kontrollcsoportokban használt digitális és nem-digitális játék.

A figyelmi müködés vizsgálatára az előző kutatásban bemutatott Navontesztet használtuk (Navon, 1977; Sjöwall et al., 2015), mely ezúttal tableten futott (programozta: Jurányi Zsolt). A tesztet három részletben vettük fel. Az első részben a gyerekek megismerkedtek a teszttel, és begyakorolták, hogy adott ábra esetén melyik gombot kell megnyomni. A második és harmadik részben háromhárom altesztet vettünk fel random sorrendben: szelektív-lokális, szelektív-globális és megosztott figyelmi alteszteket (egy alteszt nyolc próbát tartalmazott). Az első és második rész után egyperces szünetet tartottunk. A három részre bontott Navon-teszt mindegyik részét megelőzte az adott csoporthoz tartozó kezelés, vagyis összesen hat $(3 \times 2)$ percig játszottak a játékokkal a gyerekek. (1. táblázat) Az elemzésbe a hibázást vontuk be függő változóként. 
1. táblázat

Az egyes tesztszakaszok idöbeli sorrendje és idötartama

\begin{tabular}{|l|l|}
\hline \multicolumn{2}{|c|}{ Tesztszakaszok és azok időtartama } \\
\hline \multicolumn{1}{|c|}{ Tesztszakasz } & \multicolumn{1}{|c|}{ Időtartam } \\
\hline Kezelés [lassú digitális/ gyors digitális/ nem-digitális játék] & 2 perc \\
\hline Navon-teszt: gyakorlás & $\sim 2$ perc \\
\hline Szünet & 1 perc \\
\hline Kezelés [lassú digitális/ gyors digitális/ nem-digitális játék] & 2 perc \\
\hline Navon-teszt (3 alteszt random sorrendben) & $\sim 4$ perc \\
\hline Szünet & 1 perc \\
\hline Kezelés [lassú digitális/ gyors digitális/nem-digitális játék] & 2 perc \\
\hline Navon-teszt (3 alteszt random sorrendben) & $\sim 3$ perc \\
\hline
\end{tabular}

\section{Eredmények}

Először azt vizsgáltuk, hogy a szelektív és megosztott figyelmi helyzetben van-e különbség a csoportok teljesítménye (hibaszám) között, amit általánosított lineáris kevert modellel (GzLMM) vizsgáltunk. Szignifikáns interakciós hatást kaptunk $\left(\mathrm{F}_{4 ; 2452}=2,661 ; \mathrm{p}=0,031\right)$ : a nem-digitális (kontroll) és a lassú digitális játékkal játszók a szelektív figyelmi feladatban több helyes választ adtak, mint a megosztott figyelmi feladatban (nem-digitális: $\mathrm{F}_{2: 857}=2,715$; $\mathrm{p}=0,067$; lassú digitális: $\left.\mathrm{F}_{2 ; 920}=11,308 ; \mathrm{p}<0,001\right)$, ez a tendencia azonban a gyors digitális játék után nem jelent meg $\left(\mathrm{F}_{2 ; 675}=0,146 ; \mathrm{p}=0,864\right)$.

Ezt követően azt vizsgáltuk, hogy az egyes teszthelyzeteken belül (szelektív, illetve megosztott) a kezelés hogyan befolyásolta a lokális és a globális ingerek feldolgozását, amelyhez szintén általánosított lineáris kevert modelleket (GzLMM) használtunk. A megosztott figyelmi helyzeten belül szignifikáns interakciós hatást kaptunk $\left(\mathrm{F}_{6 ; 793}=2,202 ; \mathrm{p}=0,041\right)$ : a digitális csoportokban a lokális próbákon (amikor a kis ábra volt a célinger) jobban teljesítettek a gyerekek, mint a globális próbákon (amikor a nagy ábra volt a célinger), míg a nem-digitális csoportban fordítva, bár a post hoc tesztek nem minden esetben voltak szignifikánsak. (6. ábra) Összehasonlítva az egyes csoportokat, azt találtuk, hogy a lokális próbákban nem volt köztük szignifikáns különbség, a globális próbákban azonban a nem-digitális csoport jobban teljesített a lassú digitális csoporthoz képest $\left(\mathrm{F}_{2 ; 193}=3,075 ; \mathrm{p}=0,048\right)$.

A szelektív figyelmi feladaton belül nem volt különbség a csoportok teljesítménye között. 


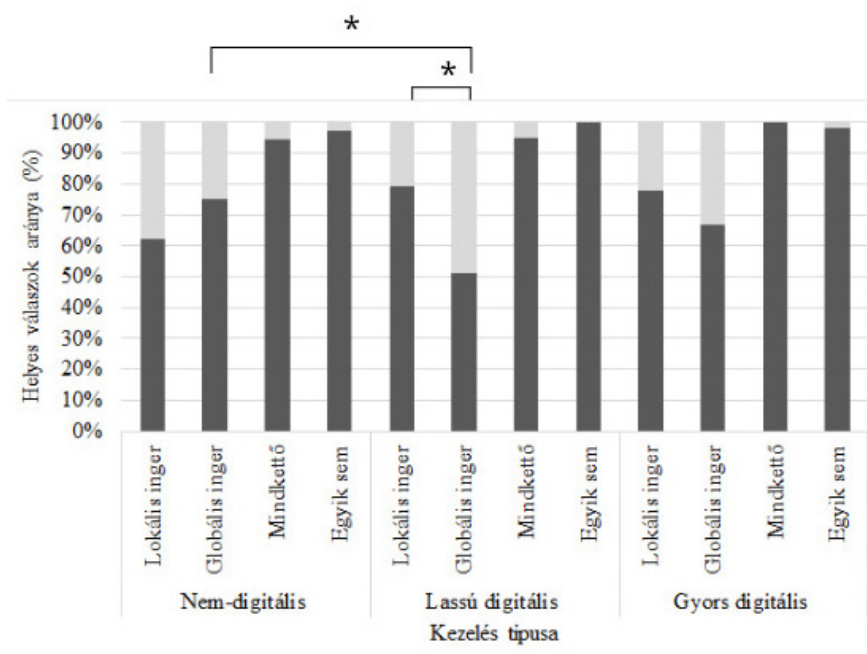

6. ábra

A helyes válaszok aránya (\%) a Navon-teszt megosztott figyelmi altesztjében a gyors digitális, a lassú digitális és nem-digitális csoportokban.

\section{Összegzés}

\section{Figyelem}

A figyelmi működéssel kapcsolatban mindkét kutatás eredménye alátámasztja, hogy a gyerekek teljesítménye jobb a szelektív figyelmet igénylő feladatokban, mint a megosztott figyelmi múködést követelő feladatok esetében. Ez egybevág azzal az elképzeléssel, amely szerint a figyelem fó funkciója a releváns ingerek kiszürése a zajos környezetből, és amely szerint a figyelem megosztása teljesítményromláshoz vezet (Courage, Bakhtiar, Fitzpatrick, Kenny, \& Brandeau, 2015). Érdekes módon a 2. kutatásban a szelektív figyelmi feladatokban mutatott előny eltűnt a gyors ÉKM-játék után. Felnőttek esetében számítógépes játékok játszása után javul a megosztott figyelmi helyzetekben mért teljesítmény (Greenfield, DeWinstanley, Kilpatrick, \& Kaye, 1994), vagyis lehetséges, hogy az ÉKM-en játszható játékok fejlesztik a figyelemmegosztás képességét már gyerekeknél is. A digitális játékok során a felhasználók sokféle ingernek vannak kitéve, valamint gyakran az is a játék célja, hogy egyszerre több dolgot figyeljenek, ahogy ez a kutatásunkban alkalmazott lufis játékban is történt. A gyerekek elméje gyorsan alkalmazkodik az adott környezethez (például Rothbart \& Posner, 2015), ezért elképzelhető, hogy már a kétperces játék is hatással volt a figyelemmegosztási képességre. Ugyanakkor az a magyarázat is helytálló lehet, hogy az ÉKM-játék valójában csak a szelektív figyelmet rontotta, hiszen nem fordult át a 
szelektív figyelmi helyzet előnye a megosztott figyelmi helyzet javára, csak eltünt a különbség a kettő között. Egyre több adat utal arra, hogy a különböző digitális tartalmak közti oda-vissza váltogatás megterheli a felhasználó figyelmét, és felületes feldolgozáshoz, valamint az irreleváns ingerek kiszürésének gyengüléséhez vezet (Bowman, Levine, Waite, \& Gendron, 2010; Ophir, Nass, \& Wagner, 2009).

A lokális-globális fókusz kapcsán mindkét kutatásban azt találtuk, hogy a megosztott figyelmi helyzetben az ÉKM-et nem használó (1. kutatás) és a kísérlet során nem-digitális játékkal játszó (2. kutatás) gyerekek a globális ingerekre reagáltak gyorsabban/pontosabban; míg a rendszeres ÉKM-használó (1. kutatás) és a kísérlet során digitális játékkal játszó (2. kutatás) gyerekek a lokális ingereknél mutattak jobb teljesítményt. A lokális ingerek, vagyis a részletek feldolgozása felé eltolódó figyelmi működést magyarázhatja, hogy az ÉKM-eszközökön általában kis részletekre kell fókuszálni, valamint a használatuk nagyon precíz mozgást követel, ami a részletekre irányuló figyelmet aktivizálhatja (Job et al., 2017). A digitális kijelzőkön az egészleges képhez nem igazán van hozzáférése a felhasználónak, hiszen az újabb tartalmak betöltéséhez gyakran görgetni kell a képernyőt vagy ide-oda navigálni, ami szintén a részletek felé tolhatja a figyelmi folyamatokat (Liu, 2005).

A szelektív figyelmi feladatban azonban nem találtunk ilyen különbséget az ÉKM-használó/nem használó, vagy a kísérletben digitális/nem-digitális játékkal játszó gyerekek teljesítménye között. Vagyis, amennyiben a gyerekek figyelmét kifejezetten a globális ingerre irányítjuk, már nem mutatnak hátrányt a globális feldolgozásban. Ezek szerint az ÉKM-használó vagy a digitális játékokkal játszó gyerekeknél a globális fókusz elsőbbsége nem automatikus, mint a többieknél, és általában a tipikusan fejlődő gyerekeknél (Plaisted, Swettenham, \& Rees, 1999), de a figyelemi fókusz szándékos irányításával képesek ugyanúgy feldolgozni a globális ingereket, mint az ÉKM-et nem használó/digitális játékokkal nem játszó gyerekek. Ez az eltérés azt jelenti, hogy figyelmi képességeik másként működnek, ami fontos információ lehet a pedagógusok számára, mert elképzelhetö, hogy ezek a gyerekek más típusú feladatbemutatást igényelnek.

\section{Társas készségek: tudatelmélet és érzelemfelismerés}

Az 1. kutatás (összehasonlító vizsgálat) eredményei alapján az ÉKM-használó gyerekek tudatelméleti készségei gyengébbek voltak az ilyen eszközöket nem használó gyerekekhez képest. Ezt az eredményt magyarázhatja a korábban már említett helyettesítési hipotézis, amely szerint az online aktivitás elveszi az időt az offline tevékenységtől, például ezek a gyerekek kevesebbet játszanak a szülővel vagy más gyerekekkel (Vandewater et al., 2006). A hatás lehet fordított is, azaz lehetséges, hogy azok a gyerekek használnak inkább ilyen eszközöket, akik számára nehézséget jelent a szociális kapcsolatok kialakítása (Hoge, Bickham, \& Cantor, 2017). Autizmusspektrum-zavarral élő gyerekek sok esetben előnyben részesítik a sokkal kiszámíthatóbban működő digitális világot a nehezen érthető offline (szociális) világgal szemben, ahol 
az események közötti összefüggések nehezebben megjósolhatók számukra (Mazurek \& Wenstrup, 2013; Shane \& Albert, 2008).

Az érzelemfelismerés terén nem találtunk különbséget az ÉKM-használó és nem használó gyerekek között. Az egyik magyarázat szerint az érzelemfelismerés egy korán megjelenő, epigenetikus folyamat (de Waal, 2008). A tudatelméleti készség ezzel szemben összetettebb képesség, amelynek fejlődése sokkal lassabb, és hatékony müködéséhez számos más készség megfelelő elsajátítása is szükséges, olyan végrehajtó készségeké, mint például a válaszgátlás vagy a kognitív rugalmasság (Perner \& Lang, 1999). Így feltételezhető, hogy a megfelelő mennyiségű és minőségű társas inger hiánya nagyobb hatással van a tudatelméleti készségek fejlődésére, és kevésbé érinti az érzelemfelismeréssel kapcsolatos elmefolyamatokat.

\section{Kitekintés}

A jelen tanulmányban bemutatott kutatásaink is alátámasztják azt, hogy a most felnövő generációk kognitív és társas készségeit jelentősen befolyásolja a digitális eszközök hosszabb vagy egészen rövid távú használata. A jövőben valószínủleg még többen fognak ilyen eszközöket használni már gyermekkoruktól kezdve, sőt akár szükségszerűvé is válhat a digitális eszközök korai használata, például az oktatáshoz való hozzáféréshez, ahogy ez a jelenlegi, koronavírus miatt kialakult krízishelyzetben történik. Éppen ezért nagyon fontos minél alaposabban feltérképezni, hogy a digitális felületeken történő tevékenységek (mint például a tanulás, játék, üzenetváltás) hogyan hatnak a gyerekekre. A hatások ismeretében pedig törekedni kell arra, hogy a negatív hatásokat (kompenzáció, korlátozás) kiküszöböljük, míg az ÉKM-használat előnyeit (az oktatási anyagok gamifikálása) előtérbe helyezzük, pozitív célra használjuk.

A kutatásokból származó tapasztalatokat a gyerekeknek szóló digitális felületek tervezésekor is fel kellene használni. Az Alfa Generáció Labor egy ilyen (kezdőalkalmazásként is funkcionáló, az egész eszköz müködését átszövő) felületen dolgozik, mely alkalmazkodik a gyerekek megváltozott kognitív működéséhez, és egyúttal biztonságos közeget teremt számukra a digitális térben. Az alkalmazás, Alfi (https://www.alfageneracio.hu/alfi/) élölényszerüen viselkedik, ezzel proaktív módon igyekszik jó irányba terelni a gyermekkori digitális eszközhasználatot. Ezért támogatja a társas interakciókat, offline tevékenységeket is, az online térben pedig fejlesztő játékokkal és egy, a szülő-gyerek interakciót erősítő interaktív mesével igyekszik a gyerekek kognitív és társas-érzelmi készségeit fejleszteni. Az applikáció célja, a játékos készségfejlesztésen túl, hogy korlátozzuk a digitális aktivitást (például időkorlát felállítása), illetve az interaktív ágens, valamint a társak (szülők, testvérek stb.) bevonásával szociális ingereket is nyújtsunk a gyerekek számára. Jelenleg Alfi hatásosságának tesztelése zajlik. Távlati célunk, hogy Alfi egyfajta keretrendszerként legyen használható a pszichológiai és pedagógiai kutatásban, lehetőséget adva arra, hogy nagy mennyiségü adatot vehessünk fel gyerekekkel, például gamifikált tesztek formájában. 


\section{Köszönetnyilvánítás}

Szeretnénk megköszönni Kocsis Adriennek a tesztek lebonyolításában és Pogány Ákosnak a statisztikai elemzésben nyújtott segítséget. Köszönjük az anyagi támogatást a Nemzeti Kutatási, Fejlesztési és Innovációs Hivatalnak (ELTE Intézményi Kiválósági Program, NKFIH-1157-8/2019-DT; OTKA K124458; OTKA KH129603), az Innovációs és Technológiai Minisztériumnak (Új Nemzeti Kiválóság Program) és a Magyar Tudományos Akadémiának (Bolyai János Kutatási Ösztöndíj). A kézirat elkészítésének ideje alatt Bunford Nórát a Lendület Program (\#LP2018-3/2018) támogatta.

\section{Irodalom}

Ashiabi, G. S. (2007). Play in the preschool classroom: Its socioemotional significance and the teacher's role in play. Early Childhood Education Journal, 35(2), 199207. https://doi.org/10.1007/s10643-007-0165-8

Bowman, L. L., Levine, L. E., Waite, B. M., \& Gendron, M. (2010). Can students really multitask? An experimental study of instant messaging while reading. Computers and Education, 54(4), 927-931. https://doi.org/10.1016/j.compedu.2009.09.024

Christakis, D. A. (2009). The effects of infant media usage: What do we know and what should we learn? Acta Paediatrica, International Journal of Paediatrics. https://doi.org/10.1111/j.1651-2227.2008.01027.x

Christakis, D. A., Ramirez, J. S. B., \& Ramirez, J. M. (2012). Overstimulation of newborn mice leads to behavioral differences and deficits in cognitive performance. Scientific Reports, 2. https://doi.org/10.1038/srep00546

Connell, S. L., Lauricella, A. R., \& Wartella, E. (2015). Parental co-use of media technology with their young children in the USA. Journal of Children and Media, 9(1), 5-21. https://doi.org/10.1080/17482798.2015.997440

Courage, M. L., Bakhtiar, A., Fitzpatrick, C., Kenny, S., \& Brandeau, K. (2015). Growing up multitasking: The costs and benefits for cognitive development. Developmental Review, 35, 5-41. https://doi.org/10.1016/j.dr.2014.12.002

de Waal, F. B. M. (2008). Putting the Altruism Back into Altruism: The Evolution of Empathy. Annual Review of Psychology, 59(1), 279-300. https://doi.org/10.1146/ annurev.psych.59.103006.093625

Dunn, J., Brown, J., \& Beardsall, L. (1991). Family Talk About Feeling States and Children's Later Understanding of Others' Emotions. Developmental Psychology, 27(3), 448-455. https://doi.org/10.1037/0012-1649.27.3.448

Fonagy, P., Steele, M., Steele, H., \& Holder, J. (1997). Children securely attached in infancy perform better in belief-desire reasoning task at age five. Unpublished Manuscript.

Gentile, D. A., \& Khoo, A. (2012). Video game playing, attention problems, and impulsiveness: Evidence of bidirectional causality. Psycnet.Apa.Org, 1(1), 62-70. https://doi.org/10.1037/a0026969 
Goodrich, S. A., Pempek, T. A., \& Calvert, S. L. (2009). Formal production features of infant and toddler DVDs. Archives of Pediatrics and Adolescent Medicine, 163(12), 1151-1156. https://doi.org/10.1001/archpediatrics.2009.201

Gopnik, A., \& Astington, J. W. (1988). Children's understanding of representational change and its relation to the understanding of false belief and the appearance-reality distinction. Child Development, 59(1), 26-37. https://doi. org/10.1111/j.1467-8624.1988.tb03192.x

Green, C. S., \& Bavelier, D. (2008). Exercising Your Brain: A Review of Human Brain Plasticity and Training-Induced Learning. Psychology and Aging, 23(4), 692-701. https://doi.org/10.1037/a0014345

Greenfield, P. M., DeWinstanley, P., Kilpatrick, H., \& Kaye, D. (1994). Action video games and informal education: Effects on strategies for dividing visual attention. Journal of Applied Developmental Psychology, 15(1), 105-123. https://doi. org/10.1016/0193-3973(94)90008-6

Harris, P. L., Donnelly, K., Guz, G. R., \& Pitt-Watson, R. (1986). Children's understanding of the distinction between real and apparent emotion. Child Development, 57(4), 895-909. https://doi.org/10.1111/j.1467-8624.1986. tb00253.x

Hoge, E., Bickham, D., \& Cantor, J. (2017). Digital media, anxiety, and depression in children. Pediatrics, 140(November), S76-S80. https://doi.org/10.1542/ peds.2016-1758G

Hogrefe, G.-J., Wimmer, H., \& Perner, J. (1986). Ignorance versus False Belief: A Developmental Lag in Attribution of Epistemic States. Child Development, 57(3), 567. https://doi.org/10.2307/1130337

Hubel, D. H., \& Wiesel, T. N. (1963). Shape and arrangement of columns in cat's striate cortex. The Journal of Physiology, 165(3), 559-568. https://doi.org/10.1113/ jphysiol.1963.sp007079

Job, X. E., van Velzen, J., \& de Fockert, J. W. (2017). Grasp preparation modulates early visual processing of size and detection of local/global stimulus features. Cortex, 96(xxszám), 46-58. https://doi.org/10.1016/j.cortex.2017.08.034

Kabali, H. K., Irigoyen, M. M., Nunez-Davis, R., Budacki, J. G., Mohanty, S. H., Leister, K. P., \& Bonner, R. L. (2015). Exposure and Use of Mobile Media Devices by Young Children. Pediatrics, 136(6), 1044-1050. https://doi.org/10.1542/ peds.2015-2151

Kirkorian, H. L., Pempek, T. A., Murphy, L. A., Schmidt, M. E., \& Anderson, D. R. (2009). The impact of background television on parent-child interaction. Child Development, 80(5), 1350-1359. https://doi.org/10.1111/j.14678624.2009.01337.x

Konok, V., Bunford, N., \& Miklósi, Á. (2020). Associations between child mobile use and digital parenting style in Hungarian families. Journal of Children and Media, 14(1), 91-109. https://doi.org/10.1080/17482798.2019.1684332 
Landhuis, C. E., Poulton, R., Welch, D., \& Hancox, R. J. (2007). Does childhood television viewing lead to attention problems in adolescence? Results from a prospective longitudinal study. Pediatrics, 120(3), 532-537. https://doi. org/10.1542/peds.2007-0978

Langner, O., Dotsch, R., Bijlstra, G., Wigboldus, D.H.J., Hawk, S. T., \&van Knippenberg, A. (2010). Presentation and validation of the radboud faces database. Cognition and Emotion, 24(8), 1377-1388. https://doi.org/10.1080/02699930903485076

Liu, Z. (2005). Reading behavior in the digital environment: Changes in reading behavior over the past ten years. Journal of Documentation, 61(6), 700-712. https://doi.org/10.1108/00220410510632040

Mazurek, M. O., \& Wenstrup, C. (2013). Television, video game and social media use among children with ASD and typically developing siblings. Journal of Autism and Developmental Disorders, 43(6), 1258-1271. https://doi.org/10.1007/ s10803-012-1659-9

Miyamoto, Y., Nisbett, R. E., \& Masuda, T. (2006). Culture and the physical environment holistic versus analytic perceptual affordances. Psychological Science, 17(2), 113-119. https://doi.org/10.1111/j.1467-9280.2006.01673.x

Nathanson, A. I., Sharp, M. L., Aladé, F., Rasmussen, E. E., \& Christy, K. (2013). The relation between television exposure and theory of mind among preschoolers. Journal of Communication, 63(6), 1088-1108. https://doi.org/10.1111/ jcom.12062

Navon, D. (1977). Forest before trees: The precedence of global features in visual perception. Cognitive Psychology, 9(3), 353-383. https://doi.org/10.1016/00100285(77)90012-3

O’Reilly, H., Pigat, D., Fridenson, S., Berggren, S., Tal, S., Golan, O., ... Lundqvist, D. (2016). The EU-Emotion Stimulus Set: A validation study. Behavior Research Methods, 48(2), 567-576. https://doi.org/10.3758/s13428-015-0601-4

Ophir, E., Nass, C., \& Wagner, A. D. (2009). Cognitive control in media multitaskers. Proceedings of the National Academy of Sciences of the United States of America, 106(37), 15583-15587. https://doi.org/10.1073/pnas.0903620106

Perner, J., \& Lang, B. (1999). Development of theory of mind and executive control. Trends in Cognitive Sciences, 3(9), 337-344.

Plaisted, K., Swettenham, J., \& Rees, L. (1999). Children with Autism Show Local Precedence in a Divided Attention Task and Global Precedence in a Selective Attention Task. Journal of Child Psychology and Psychiatry, 40(5), 733-742. https://doi.org/10.1111/1469-7610.00489

Rothbart, M. K., \& Posner, M. I. (2015). The developing brain in a multitasking world. Developmental Review, 35, 42-63. https://doi.org/10.1016/j.dr.2014.12.006

Schoenmaker, C., Juffer, F., van IJzendoorn, M. H., Linting, M., van der Voort, A., \& Bakermans-Kranenburg, M. J. (2015). From maternal sensitivity in infancy to adult attachment representations: a longitudinal adoption study with secure 
base scripts. Attachment and Human Development, 17(3), 241-256. https://doi. org/10.1080/14616734.2015.1037315

Shane, H. C., \& Albert, P. D. (2008). Electronic screen media for persons with autism spectrum disorders: Results of a survey. Journal of Autism and Developmental Disorders, 38(8), 1499-1508. https://doi.org/10.1007/s10803-007-0527-5

Sjöwall, D., Backman, A., \& Thorell, L. B. (2015). Neuropsychological Heterogeneity in Preschool ADHD: Investigating the Interplay between Cognitive, Affective and Motivation-Based Forms of Regulation. Journal of Abnormal Child Psychology, 43(4), 669-680. https://doi.org/10.1007/s10802-014-9942-1

Uhls, Y. T., Michikyan, M., Morris, J., Garcia, D., Small, G. W., Zgourou, E., \& Greenfield, P. M. (2014). Five days at outdoor education camp without screens improves preteen skills with nonverbal emotion cues. Computers in Human Behavior, 39, 387-392. https://doi.org/10.1016/j.chb.2014.05.036

Vandewater, E. A., Bickham, D. S., \& Lee, J. H. (2006). Time well spent? Relating television use to children's free-time activities. Pediatrics, 117(2). https://doi. org/10.1542/peds.2005-0812

Wellman, H. M., \& Liu, D. (2004, March). Scaling of theory-of-mind tasks. Child Development. 75(2), 523-541. https://doi.org/10.1111/j.1467-8624.2004.00691.x 


\section{Konok, V., Peres K., Ferdinandy, B., Jurányi, Zs., Bunford, N., Ujfalussy, D. J. Réti, Zs., Kampis, Gy. \& Miklósi, Á.}

\section{How does mobile device use influence preschoolers' attention and socio-cognitive skills?}

Mobile touch screen devices (MTSDs: smartphones and tablets) are used by an increasingly greater number of children, at a very early age, which may influence their cognitive development, posing challenges to parents and teachers. In a cross-sectional study we tested whether pre-schoolers who frequently use MTSDs show different attentional and socio-cognitive skills than non-users. Additionally, we investigated experimentally whether children exposed to digital and non-digital games show different subsequent attentional performance, and whether the speed of the digital game matters (by exposing children to either a slow or a fast digital game). While children displayed global advantage in the selective attention task (independently of pre-existing MTSD use), MTSD users showed an atypical, local-to-global precedence in the divided attention task (faster reaction when the target stimuli was presented at the local level as opposed to the global level) and their performance in the global trials lagged behind from that of non-users. MTSD use was also associated with worse performance in theory of mind tasks, but not worse emotion recognition performance, compared to non-users. The results regarding attention control was strengthened by our experimental study: children exposed to the digital game showed a local advantage in the divided attention task but global advantage in the selective attention task, while those exposed to the non-digital game showed a global advantage in both tasks. Children playing with the slow digital and the non-digital game performed better in the selective than in the divided attention task, in contrast, those playing with the fast digital game showed no advantage of selective attention over divided attention. Our results show that short- and long-term MTSD use, and specifically, playing MTSD games leads to a more locally oriented attention, maybe because digital screens are rich in local information and the whole visual pattern is rarely seen at once. Playing with fast digital games require the user to attend multiple stimuli simultaneously, which may train divided but not selective attention. MTSD use also takes away time from social experience, which may explain why users have difficulties with higher-order socio-cognitive skills. These insights inform psychology and pedagogy, and help to develop more optimal methods for knowledge transfer.

Keywords: mobile touch screen devices, digital games, attention, socio-cognitive skills 
Konok Veronika: https://orcid.org/0000-0001-6660-3603

Peres Krisztina: https://orcid.org/0000-0001-9051-9591

Ferdinandy Bence: https://orcid.org/0000-0001-6895-9750

Jurányi Zsolt: https://orcid.org/0000-0002-3622-6533

Bunford Nóra: https://orcid.org/0000-0002-9645-604X

Ujfalussy Dorottya Júlia: https://orcid.org/0000-0001-5363-753X

Réti Zsófia: https://orcid.org/0000-0001-9659-3987

Kampis György: https://orcid.org/0000-0001-7373-9402

Miklósi Ádám: https://orcid.org/0000-0003-4831-8985 